International

Medical Society

http://imedicalsociety.org

\title{
Congenital Syphilis: Injury Panorama at a Teaching Hospital
}

Rosalete Landim de Castro Coutinho', Karla Maria Carneiro Rolim² ${ }^{2}$, Vicente Lima Crisóstomo ${ }^{3}$, Elaine Meireles Castro ${ }^{4}$, Cláudia Rejane Pinheiro Maciel Vidal ${ }^{5}$, Francisco Herlanio Costa Carvalho ${ }^{6}$, Eveliny Silva Martins ${ }^{7}$, Régia Christina Moura Barbosa Castro 8

\section{Abstract}

Establish the profile of women with syphilis in pregnancy as well as aspects of prenatal care, and the incidence and prevalence of congenital syphilis in that specific population. Documental study at a teaching maternity in Fortaleza, Ceará, Brazil. The population consisted of 787 women with syphilis diagnosed at the childbirth or curettage in the period from 2007 to 2012. The prevalence rate in pregnant women was $2.7 \%$. In relation to health care of pregnant women, $57.82 \%$ had prenatal care. However, most (59.47\%) of the diagnosis of maternal syphilis was held at childbirth or curettage and only $9.89 \%$ had proper treatment in the follow-up. Regarding the management of newborns, the data show that the majority (62.20\%) had signs and symptoms of congenital syphilis; among them, $93.30 \%$ had proper treatment, although $66.85 \%$ did not undergo X-Ray (XR) of long bones. Reducing the cases of congenital syphilis depends on the quality of the prenatal care provided to those women, through training and professional involvement to fulfill the recommendations of health policies for combating syphilis.

\section{Keywords}

Congenital Syphilis; Epidemiological Surveillance; Assistance to Health.

\section{Introduction}

In the context of health challenges, sexually transmitted infections (STIS) stand out for their ability to have a profound impact on the human
1 Nurse at the School Maternity Assis Chateaubriand (MEAC/UFC). MSc in Public Policies and Management of Higher Education from the Federal University of Ceará (POLEDUC/UFC).

$2 \mathrm{PhD}$ in Nursing from the Federal University of Ceará (UFC). Professor of the University of Fortaleza (UNIFOR).

$3 \mathrm{PhD}$ in Financial Economy from the University of Valladolid/Espanha. Professor of the Department of Accounting Sciences/College of Economy of the Federal University of Ceará. Professor of the Professional MSc in Public Policies and Management of Higher Education (POLEDUC/UFC).

4 Nurse at the School Maternity Assis Chateaubriand (MEAC/UFC). MSc in Nursing from the Federal University of Rio Grande do Norte (UFRN).

5 Nurse at the School Maternity Assis Chateaubriand (MEAC/UFC). MSc in Health Clinical Care from the State University of Ceará (UECE).

6 Department of Maternal and Child Health, Escola de Medicina, Federal University of Ceará (UFC).

7 MSc Student in Nursing by the Postgraduate Program of the Federal University of Ceará (UFC).

$8 \mathrm{PhD}$ in Nursing from the Federal University of Ceará (UFC). Professor of the Department of Nursing (UFC).

\section{Contact information:}

\section{Régia Christina Moura Barbosa.}

Address: Departamento de Enfermagem da Universidade Federal do Ceará. Rua Alexandre Baraúna, 1115. Rodolfo Teófilo, CEP: 60430-160. Fortaleza, CE, Brasil.

झ regiabarbosa@hotmail.com 
species. They are one of the most common public health problems in the world. In Brazil, the estimates of cases of infections by sexual transmission, in the sexually active population for 2014, were 937,000 for syphilis, 1,541,800 for gonorrhea, 1,967,200 for chlamydia, 640,900 for genital herpes and 685,400 for human papilloma virus (HPV) [1].

Among those diseases, there is syphilis with its alarming prevalence, especially in poor countries [2, $3]$, and a high risk of vertical transmission ranging from 30 to $100 \%$ [4]. Syphilis is an infectious, systemic and chronic-evolution disease, transmitted by Treponema pallidum, being man its sole host. The infection can be acquired by sexual or vertical form, being the last one the most frequent in urban centers, equally affecting all social layers $[6,7]$.

Irregular and infrequent condom use, low education, multiple sexual partners and little involvement with the preventive aspects also associate with the occurrence of syphilis [8].

That disease is noteworthy since two million pregnant women are infected annually by syphilis, and around $25 \%$ of those cases result in spontaneous fetal loss and another 25\%, in newborns with low birth weight or severe infection, factors that associate with an increased risk of perinatal death [9].

In Brazil, in 2011, there were 3.3 cases per 1000 live births. Between 1998 and June 2012, Brazil registered, through the System for Information of Notifiable Diseases (SINAN), 80,041 cases of congenital syphilis. Among those cases, Northeast notified 25,133 (31.4\%). In 2012, Ceará registered 965 cases with an incidence rate of 7.6 per 1,000 live births. As for 2013, the notifications reached 511 cases with a rate of 6.9 per 1000 live births [2].

The Southeast and Northeast regions had the highest numbers of cases reported in the year, respectively $45.3 \%$ and $23.5 \%$. Regarding the detection rate, the Central West (6\%), Southeast (5.8\%) and North (5.5\%) regions exceeded the national rate that year [10].
Even though congenital syphilis is an important marker of health care quality in prenatal (PN), there were 14,321 new cases in 2011 and a detection rate of five per 1,000 live births in Brazil as a whole, which also reveal an underreporting of the disease.

In the search for measuring the quality of perinatal care, specially prenatal care provided to each pregnant woman, the Ministry of Health included the rate of congenital syphilis as an evaluation indicator of primary health care in each city, having the control of the disease based on serological screening and treatment of pregnant women and partners [7]. Prevention for congenital syphilis begins with the diagnosis and treatment of pregnant women before the baby's birth. Its treatment should begin as early as possible during the pregnancy period.

The actions of health promotion and protection are essential to reorient health care models, with a strategy that aims to improve the quality of life and reduce health risks through the development of healthy public policies, providing improvements in the way of living [11].

Except for asymptomatic newborns whose mothers had proper treatment and underwent the nonreactive Venereal Disease Research Laboratory test (VDRL), the other newborns with maternal diagnosis of syphilis should be submitted to hospital treatment.

The Ministry of Health recommends diagnosis and adequate treatment, clinical, laboratory and radiographic evidence of syphilis in newborns and comparison of titration of maternal VDRL test with the fetus test at the time of birth [1].

Given that reality, the objectives of the study were: to establish the profile of pregnant women with VDRL reagent followed at a teaching maternity hospital in northeastern Brazil, as well as aspects of prenatal care and to determine the incidence and prevalence of congenital syphilis in that specific population. 


\section{Method}

This is a documental study, performed at a maternity hospital in northeastern Brazil, member of the care network at the tertiary level, located in Fortaleza - Ceará.

The sample consisted of 787 women diagnosed with syphilis during pregnancy that had the outcome of the childbirth or curettage notified by the hospital's Epidemiological Surveillance Center for congenital syphilis from 2007 to 2012, with no exclusion criteria.

The collection took place from June to November 2013 by secondary data, according to the following steps: obtaining the records and reporting forms for congenital syphilis from 2007 to 2012 in the hospital surveillance core of the research institution; search for the medical records of women treated for childbirth or curettage who had the pregnancy outcome notified for congenital syphilis; building a database with the studied variables for later comparison with SINAN database for tracking possible underreporting in the system.

The results were analyzed using STATA ${ }^{\text {TM }}$ statistical software version 11.0. There was a descriptive analysis of the data, presenting the frequency distribution and central tendency for some variables. In the inferential analysis, one analyzed the possible association between risk factors related to biological and environmental conditions (maternal and perinatal), in order to better understand the health-disease process involving the loss in women affected by syphilis. Therefore, it was possible to assess the impact of health measures taken for its control given the causes and factors affecting that disturbing reality.

Statistical analysis was performed using the chisquare test to verify the homogeneity of proportions. Additionally, there was a logit regression analysis with the outcome of stillborn delivery as dependent variable. As independent variables, the factors that may contribute to the favorable outcome of childbirth stood out, such as: undergoing prenatal, syphilis diagnosed during prenatal, appropriate treatment in prenatal care.

There was analysis of the following variables regarding the pregnant woman: sociodemographic age (age group), educational attainment (years of education), origin, occupation, self-reported race; Institutional - undergoing $\mathrm{PN}$, undergoing the treatment, the moment of diagnosis and treatment of the partner. The data present by means of figures, graphs and statistical measures.

The study was submitted to the Research Ethics Committee with human beings, in accordance with the guidelines of Resolution 466/12 of the National Health Commission (CNS), and approved under opinion 16303813500005050/2013.

\section{Results}

From 2007 - 2012, in the studied hospital, there were reports of 787 cases of congenital syphilis (CS); 537 (68.2\%) occurred in live births (LB) with 15 deaths after birth and 250 (31, 8\%), in fetal loss and stillborn (SB).

According to Table 1, one can see that, among 28,682 pregnant women, 787 were diagnosed with syphilis, with a prevalence of $2.7 \%$, whereas 537 LB had congenital syphilis.

Table 1. Prevalence rate (\%) of maternal syphilis in the studied period.

\begin{tabular}{|c|c|c|c|c|}
\hline Year & $\begin{array}{c}\text { Prevalence Pregnant } \\
\text { (\%) }\end{array}$ & $\begin{array}{c}\text { Pregnant } \\
\text { women with } \\
\text { womphilis }\end{array}$ & $\begin{array}{c}\text { LB with } \\
\text { congenital } \\
\text { syphilis }\end{array}$ \\
\hline 2007 & 1.9 & 5,259 & 105 & 65 \\
\hline 2008 & 2.6 & 5,538 & 145 & 104 \\
\hline 2009 & 2.3 & 5,358 & 128 & 77 \\
\hline 2010 & 3.1 & 4,421 & 139 & 99 \\
\hline 2011 & 2.9 & 4,362 & 130 & 84 \\
\hline 2012 & 3.7 & 3,744 & 140 & 108 \\
\hline Total & 2.7 & 28,682 & 787 & 537 \\
\hline
\end{tabular}

Source: Epidemiological Surveillance Center of the University Hospital 
Figure 1: Incidence rate of congenital syphilis per 1,000 live births.

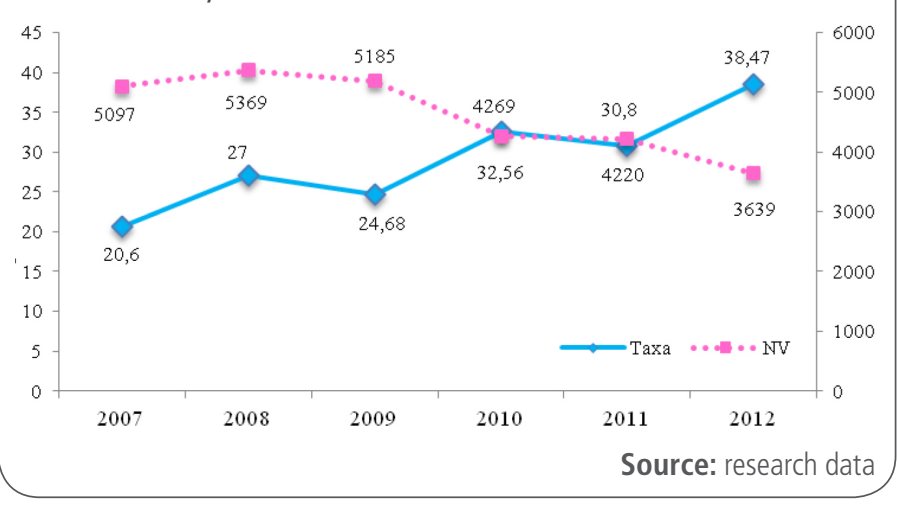

Table 2. Sociodemographic variables of the maternal syphilis attended at the school hospital from 2007 to 2012.

\begin{tabular}{|l|c|c|}
\hline Sociodemographic Characteristics & N & $\%$ \\
\hline Age group & & \\
\hline$<20$ years & 218 & 27.7 \\
\hline 20 - 29 years & 444 & 56.4 \\
\hline$\geq 30$ years & 125 & 15.9 \\
\hline Race & & \\
\hline White & 79 & 10.0 \\
\hline Black & 70 & 8.9 \\
\hline Pardo (Brown) & 521 & 66.2 \\
\hline Indigenous & 1 & 0.1 \\
\hline Ignored & 116 & 14.8 \\
\hline Years of education & & \\
\hline O years & 21 & 2.7 \\
\hline 1 - 4 years & 125 & 15.9 \\
\hline 5 - 9 years & 393 & 49.9 \\
\hline$\geq 10$ years & 185 & 23.5 \\
\hline Ignored & 63 & 8.0 \\
\hline Occupation & & \\
\hline Autonomous & 18 & 2.3 \\
\hline Domestic activities & 544 & 69.1 \\
\hline Student & 65 & 8.3 \\
\hline Other activities & 111 & 14.1 \\
\hline Ignored & 49 & 6.2 \\
\hline Origin & & \\
\hline Capital & 645 & 82.0 \\
\hline Outback & 142 & 18,0 \\
\hline Total & 787 & 100.0 \\
\hline & Source: prepared by the & $24+h o r s$ \\
\hline
\end{tabular}

Source: prepared by the authors.

As for the distribution of the incidence of congenital syphilis recorded in the historical series of the study, Figure 1 shows an upward trend, increasing by $87.9 \%$ from 2007 to 2012 (from 20.6 to 38.7 cases/1,000 live births). The average annual incidence rate of the disease during the study period was 28.3 cases per 1,000 live births $(787 / 27,779)$.

For better stratification of the sample, Table 2 presents the description of sociodemographic variables of women with syphilis.

The age of women with syphilis during the study period ranged from 12 to 46 years old with a mean of 24 years and standard deviation of 6.3. There was a greater number of cases reported among women aged 20 to 29 years, 444 (56.4\%). By analyzing the self-reported race for women, most of them selfreported brown, 521 (66.2\%). Regarding education, 393 (49.9\%) women in the sample had from five to nine years of education.

Domestic activity was the occupation most reported by the participants, 544 (69.1\%). Most of the studied patients came from the capital, 645 (82.0\%), with only 142 (18.0) from inner cities.

Regarding obstetric variables and clinical management in prenatal, Table 3 describes the main findings.

Table 3. Variable related to the management of the maternal syphilis in prenatal care.

\begin{tabular}{|l|c|c|}
\hline Sociodemographic Characteristics & N & $\%$ \\
\hline Underwent prenatal & & \\
\hline Yes & 455 & 57.8 \\
\hline No & 271 & 34.4 \\
\hline Ignored & 61 & 7.7 \\
\hline Total & 787 & 100.0 \\
\hline Moment of the maternal diagnosis & & \\
\hline Prenatal & 270 & 34.3 \\
\hline Childbirth & 468 & 59.5 \\
\hline After childbirth & 49 & 6.2 \\
\hline Total & 787 & 100.0 \\
\hline Total & 645 & 100.0 \\
\hline
\end{tabular}




\begin{tabular}{|c|c|c|}
\hline Sociodemographic Characteristics & $\mathrm{N}$ & $\%$ \\
\hline \multicolumn{3}{|l|}{ Treatment in prenatal } \\
\hline Adequate & 45 & 16.7 \\
\hline Inadequate & 171 & 63.3 \\
\hline Not performed & 54 & 20.0 \\
\hline Total & 270 & 100.0 \\
\hline \multicolumn{3}{|l|}{ Partner's treatment } \\
\hline Yes & 46 & 5.8 \\
\hline No & 741 & 94.2 \\
\hline Total & 787 & 100.0 \\
\hline \multicolumn{3}{|l|}{ Confirmatory test for syphilis } \\
\hline Performed & 55 & 7.0 \\
\hline Nor performed & 732 & 93.0 \\
\hline Total & 787 & 100.0 \\
\hline
\end{tabular}

Among the 787 pregnant women infected by Treponema pallidum, 455 (57.8\%) received prenatal care and, among those, only 270 (34.3\%) were diagnosed with the disease during that period and 468 (59.5\%), at childbirth.

As for treatment, 171 (63.3\%) of the pregnant women diagnosed with syphilis during prenatal received inadequate treatment and only 45 (16.7\%) had proper treatment. Table 3 shows that 741 (94.2\%) women did not undergo the treatment and 732 (93.0\%) did not perform the confirmatory test for syphilis.

\section{Discussion}

From 2007 to 2012, there were 4,254 cases of congenital syphilis in the state of Ceará, according to the State Department of Health (SESA) [2]. In its capital, Fortaleza, there were 2,789 notifications. The incompleteness of the information, important to ensure the indicators necessary for the evaluation of public policies for syphilis, leads us to believe there is still difficulty in treatment with the data as well as a problem of an underreporting of the disease.

Among the factors contributing to the increased incidence of a grievance as congenital syphilis, there are the conditions favorable to disease transmission and failures in attention to women's health, especiaIly in the prenatal period (PN) when infected pregnant women could receive proper diagnosis and treatment along with their partners. Other positive factors are the increase in the frequency of diagnosis and syphilis notification in pregnant women and newborns and the introduction of compulsory realization of non-treponemal test (VDRL) at childbirth as a condition for receiving the payment for the procedure by hospitals from SUS [12].

In the place where the study was conducted between the same period of 2007 to 2012, there were reported 787 cases of congenital syphilis.

The analysis of the data time series shows that the prevalence rate in pregnant women at the hospital during the study period corresponded to $2.7 \%$. Such result corresponds to an increase of almost twice when comparing with the findings of the Sentinel Study Pregnant Woman conducted by the Ministry of Health in 2011, when the rate was 1.6\% [1].

The prevalence rate of the study $(2.7 \%)$ was higher than those reported by other authors [13] in a research with pregnant women at SUS health units in the city of Rio de Janeiro, in 2007 and 2008 (1.9\%). The results also exceeded those of the sentinel study in 2006, of 1.6\% [14].

Women aged 20 - 29 years had the highest percentage, characterizing a group of young adults, who are at the peak of fertility. The results are similar to those found in previous studies $[15,16]$.

Despite the lack of relationship between the variables race and syphilis, the data from the current study are similar to those found in the Federal District, where $54.7 \%$ of women self-reported brown, followed by $25.3 \%$ of self-reported white women, black, with $15.5 \%$ and $0.45 \%$ self-reported indigenous [17]. However, there were different results in a study with pregnant women in a health facility in Rio de Janeiro, which showed a higher prevalence in women who self-reported black [13].

The study shows that the largest number of pregnant women with syphilis, 393 (49.9\%), had educa- 
tion from five to nine years, ranging from incomplete elementary school to complete elementary school, corroborating other research that reports that, in Ceará, just over $70 \%$ of the female population is illiterate, and about $80 \%$ have less than eight years of study [18].

The highest percentage of occupation of those women 544 (69.1\%) is housework. The result of this research is similar to other studies that have revealed a significant percentage of women who have no paid activity $[19,20]$.

As for the realization of prenatal of those women, this study shows that 455 (57.8\%) attended consultations, while a large quantity, 271 (34.4\%), did not underwent prenatal care. Such fact contradicts the guidance established by public policy for the elimination of congenital syphilis that the uptake of pregnant women in primary care for the realization of prenatal care should take place as early as possible [21].

Corroborating this research, which showed that 468 (59.5\%) women were diagnosed with syphilis at childbirth, a sentinel study of congenital syphilis in Brazil has documented that there is a large contingent of pregnant women with syphilis who have only the diagnosis at childbirth or curettage, despite having received prenatal, showing an annual increase in the number of cases of CS, which reveals a still very poor assistance [22].

According to the Ministry of Health, proper treatment is the one performed with crystalline penicillin in the appropriate dose for the disease stage, accomplished with, at least, 30 days before childbirth and with concomitant treatment of the partner. [23] However, among the 270 patients who had their diagnosis of syphilis during prenatal care, 171 (63.3\%) treated inappropriately and 54 (20.0\%) did not treat the disease before delivery, only 45 $(16.7 \%)$ of them had proper treatment. In another study, among the nine pregnant women diagnosed with syphilis, six had inadequate treatment and the other three did not have any registry of the treatment, demonstrating a serious public health problem [13].

Despite legislation that supports the early detection of syphilis and high prenatal coverage in the country, there is the failure of the planned routine that includes testing for HIV and VDRL, and the little investment in procedures including partner treatment of women with syphilis. [9]

That fact is evidenced in this research, because, among the 787 patients with syphilis, 732 (93.0\%) did not perform the confirmatory test for syphilis during prenatal care. An index similar to those shown in other studies [24], in which only $43 \%$ of women had had six or more prenatal consultations and, among them, only 3\% underwent one VDRL in the first quarter and the other, in the third quarter of pregnancy, as recommended by the Ministry Health. One observed that 741 (94.2\%) partners did not treat the disease, similar reality in another study [13], in which no partner received treatment for syphilis.

\section{Conclusion}

Syphilis is a serious public health problem and there is plenty to move forward in an attempt to reduce its rates, for there was a prevalence of $2.7 \%$ and an incidence of congenital syphilis with increasing trend. It is necessary to improve assistance to prenatal along with support services that work in their entirety with proper access to testing and treatment.

There was certain precariousness of that support network, since 455 (57.8\%) cases of congenital syphilis could have been avoided, given that those women underwent prenatal care. However, 185 $(40.7 \%)$ of 455 women who underwent PN did not even have their diagnosis established at that time. Among the 270 women who received the diagnosis, even during the prenatal period, 225 (83.3\%) were untreated or treated inadequately.

The results lead us to think over the existing policies in combating congenital syphilis and draw at- 
tention to the quality of care provided in primary care. It is necessary to review the practice of including syphilis more systematically in health care activities related to diagnosis and treatment for disrupting the chain of transmission. One emphasizes the importance of qualified continuing education, focused on the professionals involved in prenatal care, in order to effectively contribute to the elimination of the disease.

The research findings show the importance of seeking information about the multiple factors and conditions that influence the development of syphilis and the difficulty of managing the disease and breaking its chain of transmission. The most affected group were brown women without paid profession, aged between 20 and 29 years, from the capital and that had between five and nine years of education.

The limitations of the study were due to the incompleteness of the records, because one used secondary data. Such fact prevented collecting data such as the race/color of the mothers of those pregnant women and health facility where those women underwent their prenatal care.

One believes that this research may bring subsidies for reflection on the theme, besides leading to the development of effective actions by managers and health professionals in an attempt to reduce those rates.

\section{References}

1. Brasil. Ministério da Saúde. Secretaria de Atenção à Saúde. Departamento de Ações Programáticas Estratégicas. Política Nacional de Atenção Integral à Saúde da Mulher: Princípios e Diretrizes. Brasília: 2011.

2. Secretaria Estadual De Saúde/Ce. Governo do Estado do Ceará. Boletim Epidemiológico, 2013.

3. Pires O, Pimentel ZNS, Santos MVS, Santos WA. Vigilância epidemiológica da sífilis na gravidez no centro de saúde do bairro Uruará-Área Verde. DST J Bras Doenças Sex Transm 2007; 19:162-5

4. Schmid G. Economic and programmatic aspects of congenital syphilis prevention. Bull World Health Organ 2004; 82:402-9.
5. Secretaria de Vigilância em Saúde, Ministério da Saúde. Diretrizes para o controle da sífilis congênita. Brasília: Ministério da Saúde; 2005.

6. Veronesi R, Focaccia R. Tratado de infectologia. In: Talhari, S; Cortez, Carolina Chrusciak Talhari. Sífilis. 4. ed. São Paulo: Atheneu,VII. 1405-14, 2009

7. Campos Al De A, Araújo Mal, Melo Sp De, Gonçalves Mlc. Epidemiologia da sífilis gestacional em Fortaleza, Ceará, Brasil: um agravo sem controle. Cad. Saúde Pública [Internet]. 2010; 26(9): 1747-1755. http://dx.doi.org/10.1590/S0102311X2010000900008.

8. Figueiredo En, Vianna Lac, Peixe Mb, Ramos Vm, Succi Rcm. The challenge of the reference and counter-reference system in the prenatal assistance to pregnant women with infectious diseases. An. Acad. Bras. Ciênc. [Internet]. 2009; 81(3): 551558. http://dx.doi.org/10.1590/S0001-37652009000300018.

9. Organização Mundial De Saúde. Eliminação mundial da sífilis congênita: fundamento lógico e estratégia para ação. Genebra: 2008.

10. Brasil. Ministério da Saúde. Secretaria de Vigilância em Saúde: Departamento de DST/ Aids e Hepatites Virais. Boletim Epidemiológico Sífilis, ano I, n. 1, 2012.

11. Brasil. Agência Nacional de Saúde Suplementar. Manual técnico para promoção da saúde e prevenção de riscos e doenças na saúde suplementar - 4. ed. rev. e atual. - Rio de Janeiro: 2011.

12. Brasil. Ministério da Saúde. Sífilis. Estratégias para diagnóstico no Brasil. Ministério da Saúde. Secretaria de Vigilância em Saúde. Departamento de DST, Aids e Hepatites Virais, 2010.

13. Domingues Rmsm, Saraceni V, Hartz Zma, Leal Mc. Sífilis congênita: evento sentinela da qualidade da assistência prénatal. Rev. Saúde Pública, 2013; 47(1): 147-57.

14. Brasil. Ministério da Saúde. Secretaria em Vigilância em Saúde. Secretaria de Assistência à Saúde. Plano Operacional. Redução da Transmissão Vertical do HIV e da Sífilis, Brasília: Ministério da Saúde, 2007

15. Gondim Anc, Oliveira As, Damasceno Akc, Barbosa Bn, Pitombeira Hcs, Moraes Jl. Epidemiologia de Puérperas submetidas ao teste sorológico para a detecção da sífilis. Rev. Enfermagem UFPE, online. 2012; 6(9): 2086-2092.

16. Junior $W b$, Shiratsu $R$, Pinto $V$. Abordagem nas doenças sexualmente transmissíveis. Anais Brasileiro de Dermatologia. 2009; 84(2): 151-59, 2009

17. Tavares LHLC. et. al. Monitoramento das ações pró-redução da transmissão vertical da sífilis na rede pública do Distrito Federal. Enfermagem em Foco. 2012; 3(1): 29-35.

18. Bezerra Fjg, Kerr Lrf, Sansigolo Md De L, Barreto ML. Distribuição espacial da taxa de mortalidade infantil e principais determinantes no Ceará, Brasil, no período 2000-2002. Cad. Saúde Pública [Internet]. 2007: 23(5): 1173-1185. http://dx.doi. org/10.1590/S0102-311X2007000500019. 
19. Souza Vb, Roecker S, Marcon SS. Ações educativas durante a assistência pré-natal: percepção de gestantes atendidas na rede básica de Maringá-PR. Rev. Eletr. Enf. 2011: 13(2); 199-210. Disponível em: <http://dx.doi.org/10.5216/ree.v13i2.10162>.

20. SPINDOLA T, PENNA LH, PROGIANTI J M. Perfil epidemiológico de mulheres atendidas na consulta do pré-natal de um hospital universitário. Rev. Esc. Enferm. USP, São Paulo. 2006; 40(3): 381-388.

21. Blencowe $H$, Cousens $S$, Kamb M, Berman S, Lawn Je. Lives Saved Tool supplement detection and treatment of syphilis in pregnancy to reduce syphilis related stillbirths and neonatal mortality. BMC Public Health. 2011; 11(Suppl 3):S9. DOI:10.1186/1471-2458-11-S3-S9

22. Alves Kc De Lrp, Fram Ds, Diccini S, Belasco Ags, Barbosa DA. Prevalência e fatores de risco associados à infecção pelo Vírus da Imunodeficiência Humana em parturientes. Acta paul. enferm. [Internet]. 2009; 22(3): 307-312. http://dx.doi.org/10.1590/ S0103-21002009000300011.

23. Ministério da Saúde. Secretaria de Vigilância em Saúde. Programa Nacional de DST e Aids. Protocolo para a prevenção de transmissão vertical de HIV e sífilis. Brasília: Ministério da Saúde, 2007.

24. Rodrigues Cs, Guimarães Mdc. Grupo nacional de estudo sobre sífilis congênita. Positividade para sífilis em puérperas: ainda um desafio para o Brasil. Rev. Panamericana Saúde Pública. 2004; 16(3): 168-175.

\section{Publish in International Archives of Medicine}

International Archives of Medicine is an open access journal publishing articles encompassing all aspects of medical science and clinical practice. IAM is considered a megajournal with independent sections on all areas of medicine. IAM is a really international journal with authors and board members from all around the world. The journal is widely indexed and classified Q2 in category Medicine. 